This is an author produced version of a paper published in Restoration Ecology. This paper has been peer-reviewed and is proof-corrected, but does not include the journal pagination. The definitive version is available at www3.interscience.wiley.com.

Citation for the published paper:

Cole, Scott G. (2011) Wind power compensation is not for the birds : an opinion from an environmental economist. Restoration Ecology. Volume:

19 Number: 2

http://dx.doi.org/10.1111/j.1526-100X.2010.00771.x

Access to the published version may require journal subscription. Published with permission from: Wiley

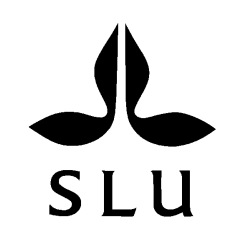

Epsilon Open Archive http://epsilon.slu.se 


\title{
(Opinion Article)
}

\section{Wind power compensation is not for the birds: An opinion from an environmental economist}

Scott G. Cole

Centre for Environmental and Resource Economics (www.cere.se)

Department of Forest Economics, Swedish University of Agricultural Sciences (SLU)

90187 Umeå

Sweden

scott.cole@sekon.slu.se

\begin{abstract}
This article advocates for better implementation of the Environmental Impact Assessment (EIA) framework as applied to wind power development, with a particular focus on improving compensatory restoration scaling. If properly enforced, the environmental impacts hierarchy "avoid - minimize - compensate" provides the regulated community with incentives to prevent wildlife and habitat impacts in sensitive areas and, if necessary, compensate for residual impacts through restoration or conservation projects. Given the increase in legislation requiring resource-based environmental compensation, methods for scaling an appropriate quantity and quality of resources is of increasing relevance. I argue that Equivalency Analysis (EA) represents a transparent and quantitative approach for scaling compensation in the case of wind power development. Herein, I identify the economic underpinnings of environmental compensation legislation and identify weaknesses in current scaling approaches within wind power development. I demonstrate how the recently-completed REMEDE Toolkit, which provides guidance on EA, can inform an improved scaling approach and summarize a case study involving raptor collisions with turbines that illustrates the EA approach. Finally, I stress the need for further contributions from the field of restoration ecology. The success of ex ante compensation in internalizing the environmental costs of wind development depends on the effective implementation of the environmental impacts hierarchy, which must effectively encourage avoidance and minimization over environmental restoration and repair.
\end{abstract}

Keywords: compensatory mitigation, compensatory restoration, Equivalency Analysis (EA), restoration scaling, Environmental Impact Assessment (EIA), no net loss 


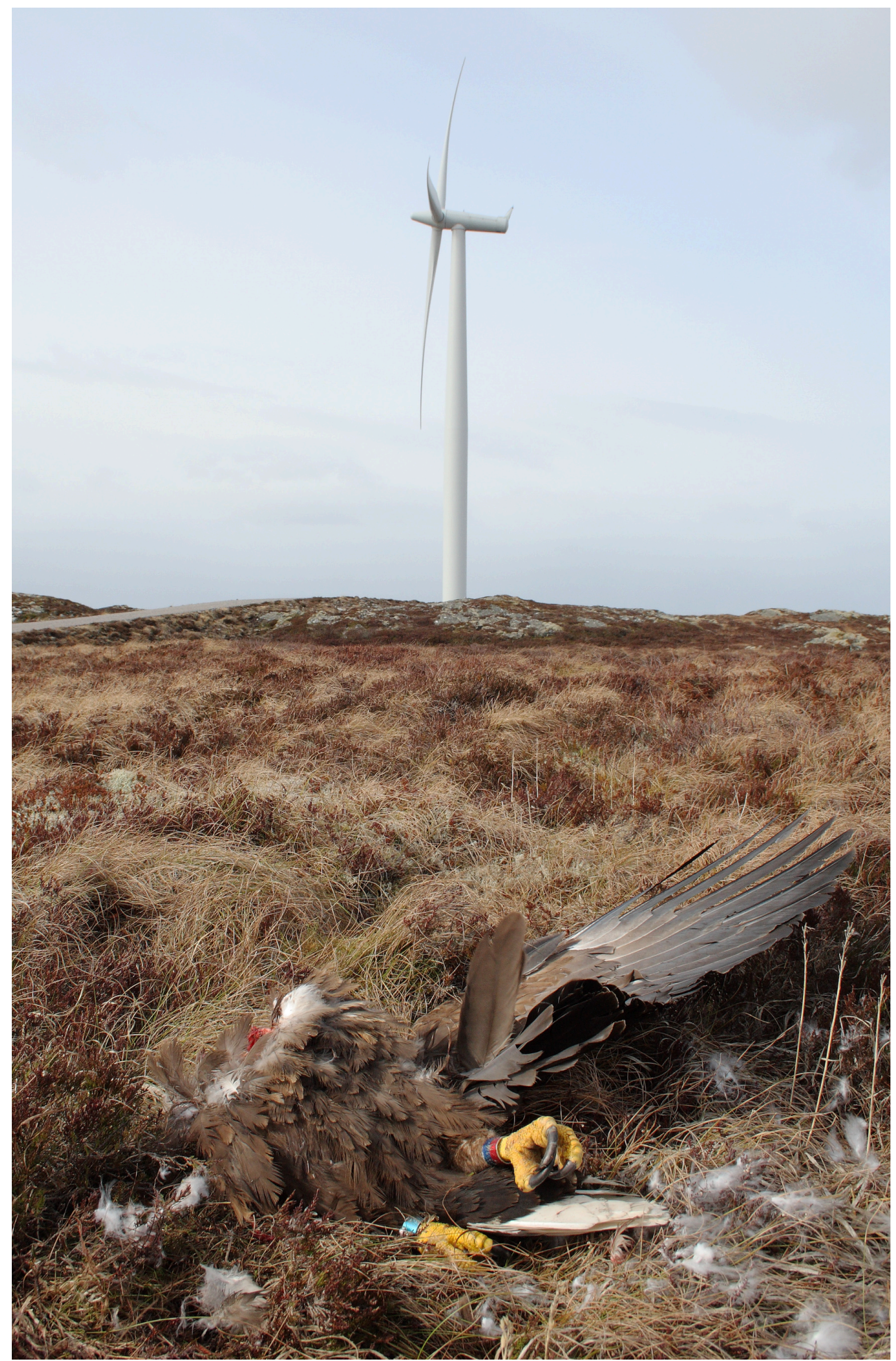

Caption: An adult White Tailed Eagle (Haliaeetus albicilla) found under Turbine \#61 on April 16, 2008. A total of 38 dead sea eagles have been found under turbines at the Smøla wind farm in Norway between 2005 and June 2010. (photo: Espen Lie Dahl, Norwegian Institute for Nature Research) 


\section{Introduction: Wind power and birds}

The issue of birds and wind turbines recently appeared in the Wall Street Journal (Bryce 2009). Based on contemporary mortality figures estimated by the wind industry and projected US windenergy goals by 2030 , the editorial extrapolated an annual mortality of 300,000 birds. Besides Altmont pass in California (Smallwood \& Thelander 2008), avian collisions have been documented in Norway (Bevanger et al. 2008), Germany (Krone et al. 2008), Spain (de Lucas et al. 2008), and Sweden (Ahlen 2008), to name a few. Although direct mortality rates from turbines vary widely (Smallwood et al. 2007) and comparisons to other causes of avian mortality are difficult (see nonrandom sampling bias in Helander et al. 2009), the risks to bird (and bat) populations are real, as is increased habitat fragmentation (Kuvlesky et al. 2007; Arnett et al. 2008; USDOE 2010). Current trends in wind energy development -- capacity worldwide has more than doubled every third year since 2005 (WWEA 2010) -- will likely exacerbate this problem.

The growth of wind development is a call for improving the science of ecological restoration to address this emerging threat to wildlife. Just as carbon emissions are external to fossil fuel production, wildlife impacts represent a spill-over effect on a third party (the public) that is external to the private costs of developing wind energy (see also noise and aesthetic impacts). One efficient way to encourage developers to internalize this external effect is through better use of the environmental impacts hierarchy in general and compensatory restoration in particular.

This paper argues for the use of Equivalency Analysis (EA) as a method to specify appropriate types and amounts of environmental compensation at wind farms. Before introducing EA and a case study in Section 5, I identify the existing policy framework for compensatory restoration (Section 2), examine the economic underpinnings of compensation (Section 3), and point to the somewhat inadequate scaling approaches used in wind development today (Section 4). Section 6 identifies improvements to the policy framework to ensure effective use of compensatory restoration.

\section{The environmental impacts hierarchy: avoid - minimize - compensate}

The pressure for wind development raises two questions: Where is the best place to put turbines and associated roads/structures to avoid and/or minimize impacts on wildlife and habitat? And how to compensate for residual environmental impacts if/when they occur?

Both questions are addressed through Environmental Impact Assessment (EIA) associated with wind development, where guidance documents suggest the "avoid-minimize-compensate" hierarchy (Langston \& Pullan 2003; WTGAC 2010). The objective is to prioritize avoidance and/or 
minimization of environmental impacts through proper siting, operational constraints, etc. Because some environmental impacts are unavoidable for otherwise socially-beneficial projects, the EIA framework allows for compensation to offset residual impacts on species and/or habitat. The objective of compensatory restoration (called compensatory mitigation in the US) is to rehabilitate or restore the quantity or quality of resources that is lost or diminished.

\section{Connecting ecology and economics: Is compensation 'for the birds'?}

Environmental economists suggest that social welfare depends on, among other things, access to natural resources and the services they provide. Damage to resources or services leads to welfare losses, which may be addressed through environmental compensation (Dunford et al. 2004). Thus, compensation is not 'for the birds' but for society in the sense that the success of environmental compensation is judged by whether it addresses the 'social welfare' metric (Because the expression 'for the birds' refers to something that is "objectionable or not worth doing," the double-meaning in this article's title is relevant: environmental economics suggests that compensation is worthwhile). Importantly, restoration that offsets welfare losses will almost certainly improve, for example, bird populations because of society's well-established preference for bird conservation -- assuming that society, with the help of ecologists and economists, can meaningfully interpret the impact of ecological protection on its collective well-being. While alternative paradigms motivate ecological restoration based on nature's intrinsic value (Clewell \& Aronson 2007), the starting point for this article is the EU and US legislation that requires compensation to address social welfare losses (Admittedly, the objective measurement of social welfare is difficult and requires ethical decisions about how to weight the well-being of different individuals in a society, see Johansson 1991).

Economic compensation is based on the notion that an individual is willing to trade-off different amounts of goods without it affecting his/her overall sense of well-being (Johansson 1991). The extent to which an individual is willing to trade one good (resource loss) for another (resource gain or money) reveals his/her preferences about what is -- and is not -- an acceptable trade-off (nonmarket environmental valuation tries to measure how individuals make these trade-offs, see Mitchell \& Carson 1989). Consider a resource-based compensation example. Without economics, an environmental loss could be replaced with an environmental gain on a simple 1-to-1 ratio: e.g., $X$ birds lost can be replaced with $X$ birds gained. But an economist would assert that the value society places on a bird lost or gained may depend on: (1) timing (a loss/gain in 50 years may be valued lower than a loss/gain that occurs today); (2) type of environmental loss/gain (the public may prefer, for example, on-site restoration gains for contamination losses but off-site conservation gains for development losses); (3) scarcity (the public may place a higher value on 
losing the last bird in a population than on losing the first); and/or (4) proximity of compensation (it is often argued that the segment of society that suffers an ecological loss should be the one that benefits from the subsequent compensation). As discussed further in Section 5, EA is designed to address these interdisciplinary issues: (1) is addressed through discounting (Cole \& Kriström 2008); (2) can be addressed by measuring public preferences when the resource/service provided through compensation differs from that which was lost (Breffle \& Rowe 2002; Thur \& Berry 2006); and (3) and (4) are addressed through criteria for compensatory project selection (see Lipton et al. 2008).

Further, economic theory suggests that compensation measures ensure efficiency (English et al. 2009). Efficiency refers to the production of goods (e.g., wind power) at the lowest possible cost to society, where all costs are included in the production decision. The intent of compensation requirements is to provide an incentive for developers to internalize the full environmental cost of siting turbines in a particular location. Consider an analogous example. Carson et al. 2003 assert that the costly compensation required of Exxon following the 1989 Valdez oil spill may explain the subsequent reduction in the number of very large oil spills in the US compared to other countries during the 1990s. That is, shipping companies doing business in US waters presumably took new measures to avoid large oil spills, thus internalizing these previously external environmental costs. Similarly, wind companies will be encouraged to avoid and minimize impacts on sensitive areas if they face the full costs of turbine development.

Because compensatory restoration addresses the loss of resource services and the associated decline in human welfare, scaling requires an interdisciplinary approach (Ozdemiroglu et al. 2009). The welfare assessment of environmental damage and subsequent compensation must be made with reference to an ecological baseline, which implies that an economist's estimation of welfare changes requires the language of ecology to characterize expected outcomes. Thus, scaling of resource-based compensation requires a merging of ecological measurement with the tools and theories of economics. Before explaining how EA fills this interdisciplinary demand, I highlight compensatory scaling approaches used in wind power development today.

\section{Current compensatory restoration for wind development}

Although practiced sporadically, compensatory restoration has been implemented by wind developers in the US and EU to address wildlife and habitat impacts (Smallwood 2008; Solano Partners 2009). Examples include, among others, acquisition of bird habitat in California (EEI 2007), and conservation of land for raptors displaced by wind development in the UK (Walker et al. 2005). 
In my opinion, current restoration scaling fails to make a connection between the extent of damage and the amount of compensation. For example, the amount of habitat conservation to offset avian collisions in California is scaled based on the "rotor-swept area of a turbine" (EEI 2007) or the megawatts generated (CCC 2005) rather than relevant collision factors and expected restoration gains to the public. Other compensatory schemes are laudable for conserving habitat, but fail to justify specific acreages using quantification metrics (monetary or otherwise). In other cases, wind proponents may fund a restoration project that would have been funded by a government agency, thus failing to provide additional environmental gains to the public.

While these "compensation" efforts are well-intentioned, I argue that scaling should be based on ecological and economic measurement to be sure the public is compensated. Below I briefly summarize Equivalency Analysis (EA) as an improved scaling methodology and illustrate its principles with a case study.

\section{Compensatory restoration scaling using Equivalency Analysis (EA)}

Under some US and European statues compensatory restoration is mandatory following environmental accidents (ex post). The practice of measuring appropriate amounts of compensation, referred to as scaling, has evolved over the last 30 years in the US (English et al. 2009). Since the mid-1990s, the primary scaling method has been EA, a quantitative approach that ensures equivalence between the environmental loss and subsequent gain (compensation) (Unsworth \& Bishop 1994; Jones \& Pease 1997; Zafonte \& Hampton 2007). For example, resource trustees in the US rely on Habitat Equivalency Analysis (HEA) or Resource Equivalency Analysis (REA) to determine how much is enough compensation (NOAA 1995). Compensation is now frequently required (or provided voluntarily) before undertaking infrastructure projects (ex ante). However, to this author's knowledge, wind power compensation has not yet been scaled using EA.

Due to the demand for compensatory scaling under the EU's Environmental Liability, Habitats, and EIA Directives, the European Commission funded REMEDE, a three-year interdisciplinary project to formalize the EA approach in a Toolkit (Lipton et al. 2008). I argue that the Toolkit's five step process, which is based on ecological and economic measurement, represents a transparent, consistent, and defensible approach which can be replicated across (wind) development projects.

EA determines how much compensation is required to offset welfare losses due to environmental damage by ensuring that the value of the environmental gain (credit) is equivalent to the value of the environmental loss (debit) over time, where value is a function of the metric used and the length of time the resource is injured (Figures 1a and 1b). The metric, or 'currency' of restoration, 
may be monetary or ecologically-based. A temporal loss in social welfare accrues because a resource takes time to recover to its baseline level as in Figure 1a (see also time discrepancy in Moilanen et al. 2008). To ensure the public suffers "no net loss" of welfare over time, EA scales compensatory resource gains such that the Figures' two shaded areas are equal. EA assumes the public is willing to substitute the value gained from a restored, enhanced or protected resource for the temporal loss in value of the damaged resource.

Figure 1a. The environmental loss (debit) in Equivalency Analysis

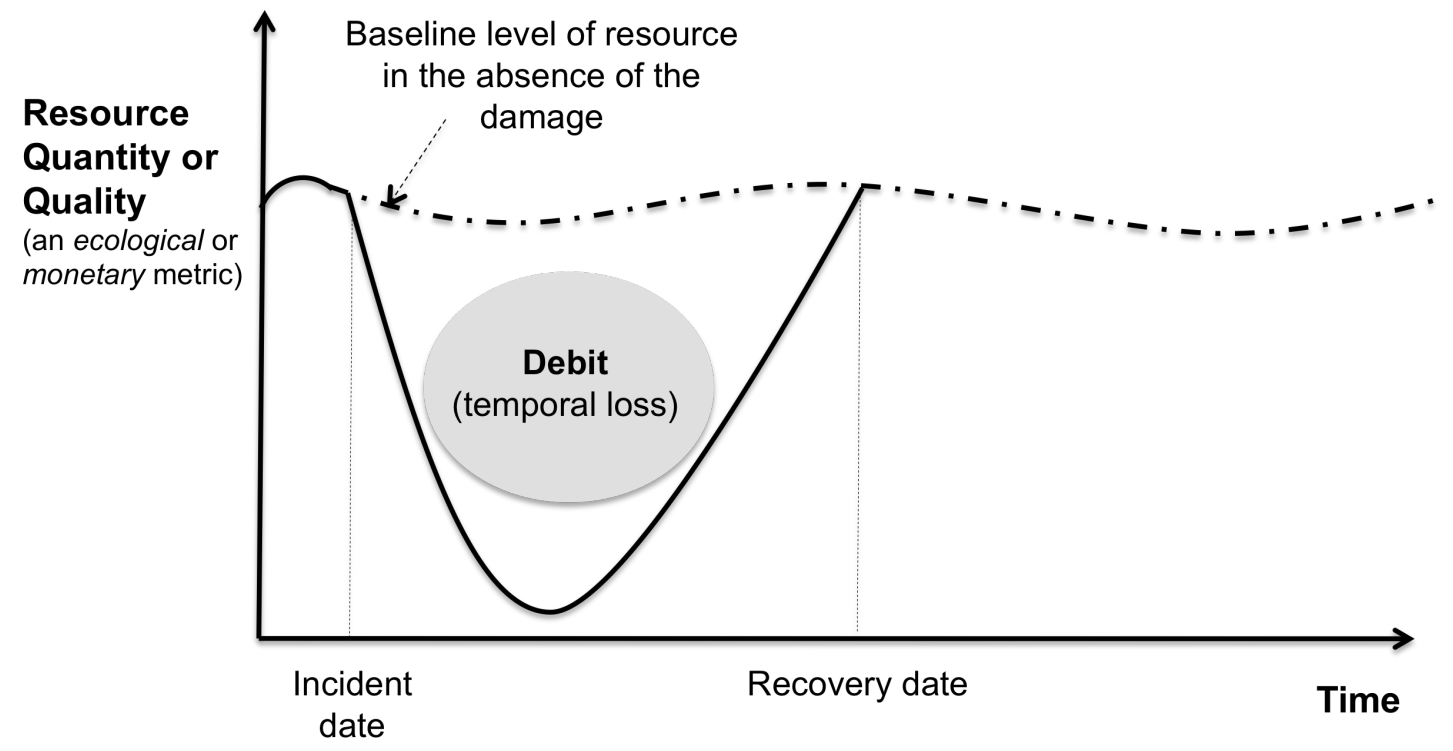

Source: Based on NOAA (1995)

The credit (Figure $1 \mathrm{~b}$ ) represents an additional and quantifiable compensatory resource gain beyond the restoration site's current and future baseline condition. Without generating additional gains, losses are not offset, leading to a "net loss" of social welfare. In general there are two mechanisms for achieving an additional gain: restoration (including rehabilitation, enhancement, re-creation) or conservation (including preservation or protection). Wetland mitigation policy in the US aims for "no net loss" and explicitly prefers restoration over conservation (FIMW 2002). Conservation arguably provides a credit in certain circumstances, although it may not address aggregate resource loss over time nor be useful in conservation-saturated areas. If a habitat will be lost under a future baseline scenario involving development, then conserving this land by sending development to less sensitive areas would lead to compensatory resource gains (Kiesecker et al. 2009). Assuming both mechanisms would offset a given temporal loss, an 
interdisciplinary EA might incorporate public preferences in selecting either restoration or conservation (see Section 3). However, land acquisition can be an expensive compensation strategy in some urban and coastal areas.

Figure 1b. The compensatory resource gain (credit) in Equivalency Analysis

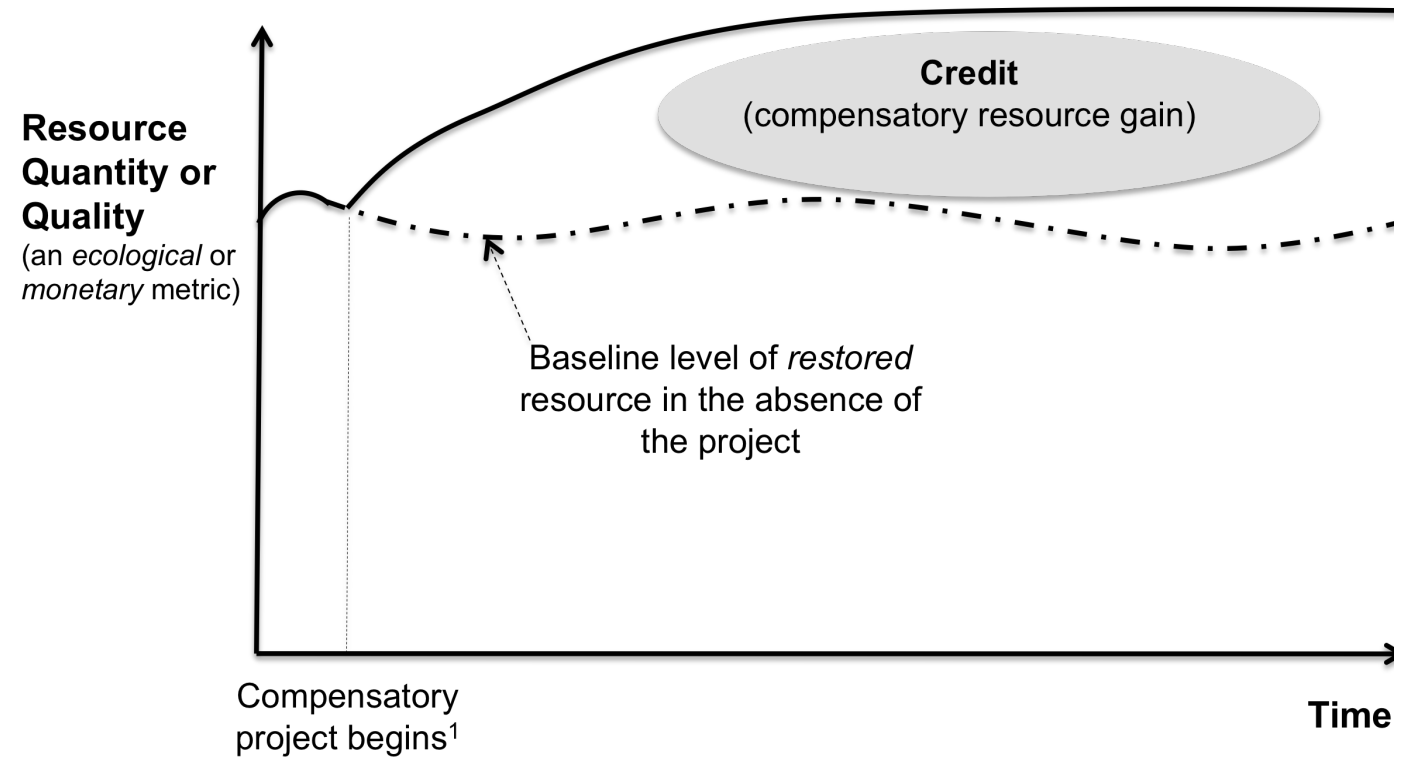

\footnotetext{
1 In theory, the credit may begin accruing before, during, or after the environmental loss.
} Source: Based on NOAA (1995)

\section{Case study: Equivalency Analysis and wind power}

Cole (2010) presents a quantitative, yet hypothetical EA case study to illustrate compensatory scaling in the case of White Tailed Eagle, WTE (Haliaeetus albicilla) collisions with wind turbines. The study, which follows the five step REMEDE process, considers the number of WTE collisions over time (past and projected losses), and quantifies the debit and credit using a "bird-year" nonmonetary metric (Zafonte \& Hampton 2005). This metric, which acts as a currency in measuring appropriate compensation, quantifies a bird's foregone life expectancy in years had it not collided with a turbine. For example, a five-year old WTE that collides with a turbine would have lived approximately 25 more years based on life history characteristics. The debit -- measured as total discounted bird-years lost -- includes both direct losses for WTEs that collide and indirect losses for offspring not born and captures the local incremental impact of turbines on top of existing human-caused mortality, e.g. electrocution, illegal hunting, habitat loss, etc. Similar approaches 
have been used to scale compensation for bird losses in the US (Swartzman 1996; Sperduto et al. 2003; IEc 2004).

A restoration project is selected based on factors limiting the WTE population. Table 1 identifies possible projects and the data required to quantify the bird-year gain. Cole (2010) illustrates the credit calculations by examining power line retrofitting near the wind farm aimed at preventing WTE electrocution. By estimating the current extent of electrocution mortality in the restoration project area -- and making assumptions about the reduction in mortality associated with the retrofit project -- the study calculates the discounted bird-years produced ("saved") per retrofitted pole, accounting for the remaining life expectancy of a WTE had it not been electrocuted (we assume retrofitting would not be undertaken in the absence of our compensatory project). Compensatory restoration is scaled by dividing the total bird-years lost (debit) by the bird-years produced per retrofitted pole which gives the number of poles to retrofit today to ensure equivalence over time between debit and credit. The use of bird-years assumes that the change in this ecological metric - both loss and gain -- is proportional to the change in society's welfare. The transparency of the EA approach is manifested through the exchange of the same restoration 'currency' across the loss and the gain side of the equation (quantified using ecological data), which is independent of the compensatory project selected from Table 1.

Table 1. Examples of compensatory projects (credit) ${ }^{1}$ that could be scaled using EA to offset White-Tailed Eagle (WTE) mortality from wind turbines

\begin{tabular}{|c|c|c|}
\hline Category & Compensatory project & Data required to quantify gain \\
\hline \multirow{3}{*}{$\begin{array}{l}\text { Reduce threats to } \\
\text { species }\end{array}$} & $\begin{array}{l}\text { Retrofit power lines to reduce } \\
\text { electrocution }\end{array}$ & $\begin{array}{l}\text { Current mortality from power lines } \& \\
\text { future reduction from retrofitting }\end{array}$ \\
\hline & $\begin{array}{l}\text { Fund measures to prevent/reduce } \\
\text { train collisions }\end{array}$ & $\begin{array}{l}\text { Current mortality from collisions \& } \\
\text { future reduction from measures }\end{array}$ \\
\hline & $\begin{array}{l}\text { Fund campaign to educate } \\
\text { hunters/lawmakers about impact of } \\
\text { lead shot on WTE }\end{array}$ & $\begin{array}{l}\text { Current mortality from lead \& future } \\
\text { reduction from campaign }\end{array}$ \\
\hline \multirow{3}{*}{$\begin{array}{l}\text { Improve breeding } \\
\text { opportunities }\end{array}$} & $\begin{array}{l}\text { Conserve and protect key habitat } \\
\text { areas }\end{array}$ & $\begin{array}{l}\text { Additional raptor production in } \\
\text { protected vs. non-protected areas }\end{array}$ \\
\hline & $\begin{array}{l}\text { Restore habitat lands already } \\
\text { protected but degraded }\end{array}$ & $\begin{array}{l}\text { Additional raptor production in } \\
\text { restored vs. non-restored areas }\end{array}$ \\
\hline & $\begin{array}{l}\text { Build artificial nests in trees or on } \\
\text { cliffs }\end{array}$ & $\begin{array}{l}\text { Additional raptor production in } \\
\text { artificial vs. adjacent natural nests }\end{array}$ \\
\hline $\begin{array}{l}\text { Improve breeding } \\
\text { success }\end{array}$ & $\begin{array}{l}\text { Protect (or enhance) WTE nests from } \\
\text { predators or human disturbance }\end{array}$ & $\begin{array}{l}\text { Additional raptor production in } \\
\text { protected vs. adjacent natural nests }\end{array}$ \\
\hline Other & $\begin{array}{l}\text { Re-introduce WTE to previously } \\
\text { occupied areas }\end{array}$ & $\begin{array}{l}\text { Population increase in re-introduction } \\
\text { area }^{2}\end{array}$ \\
\hline
\end{tabular}




\section{Improving the environmental impacts hierarchy}

Under US and EU statutes requiring ex post compensation economic incentives -- in the form of penalties, fines, and clean-up requirements -- encourage operators to prioritize damage prevention (avoidance/minimization) over environmental repair (compensation). In contrast, ex ante compensation schemes (e.g., wind power) prefer avoidance/minimization over repair but lack the economic incentives to steer project proponents toward the former rather than the latter, i.e., there are no penalties or fines for failing to adequately avoid or minimize. The lack of proper incentives makes it difficult to integrate the "avoid-minimize-compensate" hierarchy into coherent EIA guidance. As a result, existing ex ante compensation projects are generally ad hoc and the compensation component of the hierarchy is vulnerable to misuse (see "license to trash" in McKenney \& Kiesecker, 2010). Thus, ex ante compensation schemes should better define: (1) how much avoidance/minimization is enough? (Kiesecker et al. 2010) And (2) when and how much compensation is required? I address these issues below.

First and foremost, we should improve the transparency and credibility of the EIA process by improving our understanding of environmental impacts at proposed wind development sites (GAO 2005). This will reduce the uncertainties associated with (1) estimating future compensation requirements today and (2) identifying which impacts should be avoided/minimized and which can be addressed through compensation. Solano Partners (2009) suggests that the lack of clear guidance on allowable levels of impact and required amounts of compensation - a key complaint from the wind industry - is due to our poor understanding of wind power's environmental impacts. This lack of knowledge makes cost-effective management of such impacts challenging. Thus, we should strive at a minimum for mandatory pre- and post-construction monitoring surveys (e.g., Kunz et al. 2007). Site-specific data should be collected cooperatively between wildlife agencies, local ecological experts and developers, and made publically available so that other wind proposals can be reviewed in light of these data (Maisonneuve, C, 2009, Quebec MNR, personal communication); see also AWWI (2010) for a promising development in this regard). Finally, when data are diligently collected but unforeseen impacts arise, they could be addressed through ex post compensation (see recommendations in WTGAC, 2010, Chapter 4).

To address the issue of how much avoidance is enough, we could incorporate society's preferences for avoidance over compensation directly into the environmental loss calculation. In practice, this would imply a higher marginal value for each lost unit (e.g., bird-year), such that the value of the temporal loss (debit) increases exponentially (J. Dwyer, 2009, Virginia Tech, personal communication). A larger debit requires greater (and more costly) compensation, making avoidance more attractive (In theory, the marginal value could increase until we reach society's "unacceptable" level of damage -- at this point, the debit is infinite and cannot be compensated. 
Avoidance is the only option). An economic survey of the public could measure the intensity of society's preferences, e.g., how they trade-off bird losses from turbines against bird gains from compensation projects.

The implementation of the impacts hierarchy could be improved through a "reclamation fund" that wind power companies pay into prior to development. Funds are used only if damage occurs and returned (with interest) in the absence of future damage, where damage is defined in a preconstruction contract. Similar funds exist to compensate for losses associated with reduced migratory fish runs from hydropower production (BPA 2010). Similarly, oil producers/importers in the US pay into a fund to cover costs of, among other things, compensatory restoration when damage exceeds liability limits (USCG 2006). A fund provides firms with an incentive to undertake avoidance and mitigation measures to ensure re-capturing of reclamation funds while also ensuring the public receives compensation for any possible future environmental losses.

Finally, we need to improve our ability to restore affected populations and damaged ecological systems -- a key challenge for readers of this journal. This requires mandatory reporting of postrestoration monitoring to determine what works, what does not, and how much it costs. This journal's new focus on "failed" projects is an important effort in this regard (Hobbs 2009), as is the evidence-based approach to conservation (conservationevidence.com). Wilkinson et al. (2009) note that the future of compensatory restoration will require cooperation across scientists, agencies and developers through comprehensive region-wide projects, which may provide greater ecological benefits at a lower cost to society.

\section{Implications for the practice}

- Compensatory restoration activity is increasing in Europe and the US -- based either on new legal requirements or on the voluntary action of the regulated community.

- The Environmental Impact Assessment (EIA) process for constructing a wind farm includes provisions for compensatory restoration, and thus an opportunity to improve the science and practice of ecological restoration.

- Equivalency Analysis (EA) represents a transparent and quantitative method to match loss and gain in scaling compensatory restoration. Its use of an ecological or monetary metric ('currency') can be used to improve existing compensation efforts by the wind industry .

- The success of EA within wind development requires expertise from restoration ecologists. Besides innovative restoration projects for raptors and bats, practitioners should consider region-wide compensatory projects that dovetail with wildlife action plans. 
- Compensatory restoration aimed at improving social welfare underscores the importance of measuring ecological change so that the public can understand how such changes affect their well-being.

- The objective of the "avoid-minimize-compensate" hierarchy is to prevent damage from occurring rather than repairing it afterwards, but doing so requires that (wind) project proponents internalize all external costs of their projects, including the temporal loss to the public.

\section{Acknowledgments}

The author acknowledges support from the Swedish Environmental Protection Agency through the PlusMinus Project and the Swedish Research Council Formas. I appreciate valuable input and discussion on the topic from Bob Unsworth (Industrial Economics Inc.), James Dywer and Rick Harness (EDM), Bob Lehman (US Geologic Survey, retired), and Espen Lie Dahl (Norway Institute for Nature Research). Special thanks to participants of the Raptor Research Foundation Conferences in Pitlochry, Scotland (2009) and Fort Collins, Colorado (2010) for welcoming an economist into their research world. Finally, the author thanks three anonymous referees.

\section{References}

Ahlen, I. 2008. Vindkraft - ett hot för fåglar och fladdermöss? (Wind power - a threat for birds and bats?). In Swedish. Biodiverse 13 No. 1: 10-11. URL http://biodiverse.wordpress.com/2009/04/27/vindkraft-\%E2\%80\%93-ett-hot-for-faglar-ochfladdermoss/ [accessed on 10 March 2010]

Arnett E.B., Brown W.K., Erickson W.P., Fiedler J.K., Hamilton B.L., Henry T.H., Jain A., Johnson G.D., Kerns J., Koford R.R., Nicholson C.P., O'connell T.J., Piorkowski M.D., Tankersley R.D. 2008. Patterns of Bat Fatalities at Wind Energy Facilities in North America. Journal of Wildlife Management. 72 No. 1: 61-78.

(AWWI) American Wind and Wildlife Institute. 2010. Request for Proposal: AWWI Research Initiative Wind Wildlife Research Information System. Contact: Dr. Judd A. Howell, Research Director. URL http://awwi.org/uploads/files/AWWI\%20Research\%20Information\%20System\%20RFP\%20F inal.pdf [accessed 21 July 2010].

Bevanger, K., S. Clausen, E. Lie-Dahl, Ø. Flagstad, A. Follestad, J.O. Gjershaug, D. Halley, F. Hanssen, P.Lund-Hoel, K.-O. Jacobsen, L. Johnsen, R. May, T. Nygård, H.C. Pedersen, O. Reitan, Y. Steinheim, R. Vang. 2008. "Pre- and post-construction studies of conflicts between birds and wind turbines in coastal Norway." Progress Report 2008. NINA Report 409. 55 pp. URL www.nina.no/archive/nina/PppBasePdf/rapport/2008/409.pdf [accessed on 10 January 2010]. 
(BPA) Bonneville Power Administration. 2010. BPA Statutes. Revised June. See "838i. Bonneville Power Administration fund." URL: http://www.bpa.gov/corporate/docs/BPA-Statutes.pdf [accessed 21 July 2010].

Breffle, W. S. \& Rowe, R. D. 2002. Comparing Choice Question Formats for Evaluating Natural Resource Tradeoffs. Land Economics. 78 No. 2: 298.

Bryce, R. 2009. Opinion: Windmills Are Killing Our Birds. The Wall Street Journal. September 7, section: Commentary.

Carson, R., R. Mitchell, M. Hanemann, R. Kopp, S. Presser, P. Ruud. 2003. Contingent Valuation and Lost Passive Use: Damages from the Exxon Valdez Oil Spill. Environmental and Resource Economics 25 No. 3: 257-286.

Clewell, A., \& J. Aronson. 2007. Ecological Restoration: Principles, Values, and Structure of an Emerging Profession. 1st ed. Island Press, January 15.

Cole, S.G. \& B.G. Kriström. 2008. Annex 5: Discounting. In: REMEDE Toolkit (see Lipton et al 2008). URL:

http://www.envliability.eu/docs/D13MainToolkit_and_Annexes/D13MainToolkit.html [accessed 20 September 2009].

Cole, S.G. 2010. "How much is enough?" Determining adequate levels of environmental compensation for wind power impacts using equivalency analysis: An illustrative \& hypothetical case study of sea eagle impacts at the Smøla Wind Farm, Norway. Epsilon Open Archive Publishing, Swedish Agricultural University. URL: http://pubepsilon.slu.se:8080/ [accessed 28 May 2010].

(CCC) County of Contra Costa. 2005. Final Environmental Impact Report: Buena Vista Wind Energy Project LP\#022005. Community Development Department. April. URL http://www.co.contra-costa.ca.us/DocumentView.aspx?DID=1108 [accessed 21 July 2010].

Dunford R.W., Ginn T.C., Desvousges W.H. 2004. The use of habitat equivalency analysis in natural resource damage assessments. Ecological Economics 48:49-70.

Dwyer, J. 2009. Personal communication with PhD Student, Department of Fisheries and Wildlife Sciences, Virginia Tech. October 11.

(EEI) Ecology and Environment Inc. 2007. Montezuma Wind Project Final Environmental Impact Report. Prepared for Solano County Department of Resource Management. URL http://www.montezumawind.ene.com/final.aspx [accessed on 12 September 2009].

English, E.P., C.H. Peterson, C.M. Voss. 2009. Ecology and Economics of Restoration Scaling, Final Report for Coastal Response Research Center, Appendix C. URL http://rfp.crrc.unh.edu/projects/viewProject.php?PROJECT_ID=25 [accessed 10 April 2010].

(FIMW) Federal Interagency Mitigation Working Group. 2002. National Wetlands Mitigation Action Plan. URL http://www.epa.gov/owow/wetlands/pdf/map1226withsign.pdf [accessed 19 July 2010]. 
(GAO) Government Accounting Office. 2005. Wind Power: Impacts on Wildlife and Government Responsibilities for Regulating Development and Protecting Wildlife. GAO-05-906 September 16. URL http://www.gao.gov/products/GAO-05-906 [accessed 21 July 2010].

Helander, B., \& T. Stjernberg. 2003. Species Action Plan for the Conservation of White-tailed Eagle. Birdlife International, Convention on the Conservation of European Wildlife and Natural Habitats. URL http://www.coe.int/t/dg4/cultureheritage/conventions/bern/TPVS/sc22_inf02rev_en.pdf [accessed July 14, 2009].

Helander B., J. Axelsson, H. Borg, K. Holm, A. Bignert. 2009. Ingestion of lead from ammunition and lead concentrations in white-tailed sea eagles (Haliaeetus albicilla) in Sweden. Science of the Total Environment. 407 No 21: 5555-5563.

Hobbs, R. 2009. Looking for the Silver Lining: Making the Most of Failure. Restoration Ecology 17 No. 1: 1-3.

(IEc) Industrial Economics, Inc. 2004. Final Lake Apopka Natural Resource Damage Assessment and Restoration Plan. Prepared for US Fish and Wildlife Service, June. URL www.sjrwmd.com/lakeapopka/pdfs/DARP.pdf [accessed on 20 September 2009]

Johansson, P.O. 1991. An Introduction to Modern Welfare Economics. Cambridge University Press.

Jones, C.A., \& K.A. Pease. 1997. Restoration-based compensation measures in natural resource liability statutes. Contemporary Economic Policy 15 No. 4:111-122.

Kiesecker, J.M., H. Copeland, A. Pocewicz, N. Nibbelink, B. McKenney, J. Dahlke, M. Halloran, D. Stroud. 2009. A Framework for Implementing Biodiversity Offsets: Selecting Sites and Determining Scale. Bioscience 59: 77-84.

Kiesecker, J.M., H. Copeland, A. Pocewicz, B. McKenney. 2010. Development by Design: Blending Landscape-level Planning with the Mitigation Hierarchy. Frontiers in Ecology and the Environment. 8 No. 5, pp. 261-266.

Krone, O., T. Grunkorn, M. Gippert, T. Durr. 2008. White-tailed Sea Eagles and wind power plants in Germany - preliminary results. In Birds of Prey and Wind Farms. Documentation of an International Workshop in Berlin, 21-22 October (Ed. H. Hötker). Germany. URL http://bergenhusen.nabu.de/imperia/md/images/bergenhusen/bmuwindkraftundgreifwebsite/ birds_of_prey_and_windfarms_documentation_2009.pdf [accessed 10 May 2010].

Kuvlesky Jr., W.P., L.A. Brennan, M.I. Morrison, K.K. Boydston, B.M. Ballard, F.C. Bryant. 2007. Wind Energy Development and Wildlife Conservation: Challenges and Opportunities. Journal of Wildlife Management. 71 No. 8:2487-2498.

Langston, R.W., \& J.D. Pullan. 2003. Windfarms and birds: an analysis of the effects of wind farms on birds, and guidance on environmental criteria and site selection issues. By BirdLife International to the Council of Europe, Bern Convention. RSPB/Birdlife in the UK. URL www.birdlife.org/eu/pdfs/BirdLife_Bern_windfarms.pdf [accessed on 10 September 2009]. 
Kunz, T. H., E. B. Arnett, B. M. Cooper, W. P. Erickson, R. P. Larkin, T. Mabee, M. L. Morrison, M. D. Strickland, J. M. Szewczak. 2007. Assessing Impacts of Wind-Energy Development on Nocturnally Active Birds and Bats. Journal of Wildlife Management. 71: 2449-2486.

Lipton, J., K. LeJeune, J. Calewaert, E. Ozedemiroglu. 2008. Toolkit for Performing Resource Equivalency Analysis to Assess and Scale Environmental Damage in the European Union. Produced by the Resource Equivalency Methods for Assessing Environmental Damage in the EU (REMEDE) Team. Funded by the Sixth Framework Programme of the EC. September. URL http://www.envliability.eu/docs/D13MainToolkit_and_Annexes/D13MainToolkit.html [accessed 20 September 2009].

de Lucas, M, G.F.E. Janss, D.P. Whitfield, M. Ferrer. 2008. Collision fatality of raptors in wind farms does not depend on raptor abundance. Journal of Applied Ecology 45 No. 6: 16951703.

Maisonneuve, C. 2009. Email Communication with Wildlife Biologist, Quebec Ministry of Natural Resources (MNR). October 30.

McKenney, B. \& J. Kiesecker. 2010. Policy Development for Biodiversity Offsets: A Review of Offset Frameworks. Environmental Management. 45 No. 1: 165-176.

Mitchell R. \& R. T. Carson. 1989. Using .Surveys To Value Public Goods: The Contingent Valuation Method. Resources for the Future, Washington, D.C.

Moilanen, A., A.J.A.V Teeffelen, Y. Ben-Haim, S. Ferrier. 2008. How much compensation is enough? A framework for incorporating uncertainty and time discounting when calculating offset ratios for impacted habitat. Restoration Ecology 17 No. 4:470-478.

(NOAA) National Oceanic and Atmospheric Administration. 1995 . Habitat Equivalency Analysis: An Overview. Originally published March 1995; Updated 2001 and 2006. URL http://www.darrp.noaa.gov/library/pdf/heagenl.pdf [Accessed 23 June 2010].

Ozdemiroglu, E., Kriström, B., Cole, S., Riera, P. \& Borrego, D. A. 2009. Environmental Liability Directive and the use of economics in compensation, offsets and habitat banking. In: Proceedings of UK Network for Environmental Economists, London, England, March.

Smallwood, K. S., C. G. Thelander, M. L. Morrison, L. M. Rugge. 2007. Burrowing owl mortality in the Altamont Pass Wind Resource Area. Journal of Wildlife Management 71:1513-1524.

Smallwood, K.S. 2008. Mitigation in U.S. Wind Farms. In Birds of Prey and Wind Farms. Documentation of an International Workshop in Berlin, 21-22 October (Ed. H. Hötker). Germany. URL http://bergenhusen.nabu.de/imperia/md/images/bergenhusen/bmuwindkraftundgreifwebsite/ birds_of_prey_and_windfarms_documentation_2009.pdf [accessed 10 May 2010].

Smallwood, K. S. \& C. G. Thelander. 2008. Bird mortality in the Altamont pass wind resource area, California. Journal of Wildlife Management. 72: 215-223. 
Solano Partners, Inc. 2009. Enabling Progress: Compensatory Mitigation Scenarios for Wind Energy Projects in the U.S. Prepared for the American Wind and Wildlife Institute.

September. URL http://awwi.org/uploads/files/AWWI\%20Mitigation\%20Report\%20Enabling\%20Progress.pdf [accessed 19 July 2010].

Sperduto, M.B., S.P. Powers \& M. Donlan. 2003. Scaling restoration to achieve quantitative enhancement of loon, seaduck, and other seabird populations. Marine Ecology Progress Series 264: 221-232.

Swartzman, G. 1996. Resource modeling moves into the courtroom. Ecological Modeling. 92: 277288.

Thur, S. \& K. Barry. 2006. The public's habitat preferences: an analysis: Final summary report of the cross-habitat study focus groups. NOAA. January 24 . URL http://www.darrp.noaa.gov/economics/studies.html [accessed 28 June 2010].

Unsworth, R.E. \& Bishop, R.C. 1994. Assessing natural resource damages using environmental annuities. Ecological Economics 11 No. 1:35-41.

(USCG) United Stated Coast Guard. 2006. Oil Spill Liability Trust Fund (OSLTF) Funding for Oil Spills. NPFCPUB 16465.2. January. URL http://www.uscg.mil/npfc/docs/PDFs/OSLTF_Funding_for_Oil_Spills.pdf [accessed 4 May 2010].

(USDOE) United States Department of Energy. 2010. Wind Turbine Interactions with Birds, Bats, and their Habitats: A Summary of Research Results and Priority Questions. Contract No. DE-AT01-07EE11218. Spring. URL http://www.nationalwind.org//publications/bbfactsheet.aspx [accessed 28 June 2010].

Walker, D., M. McGrady, A. McCluskie, M. Madders, D.R.A. McLeod. 2005. Resident Golden Eagle ranging behaviour before and after construction of a windfarm in Argyll. Scottish Birds 25: 24-40.

Wilkinson, J.B., J.M. McElfish Jr., R. Kihslinger, R. Bendick, B. McKenney. 2009. The next generation of mitigation: linking current and future mitigation programs with state wildlife actions plans and other state and regional plans. Prepared by the Environmental Law Institute and The Nature Conservancy. August 4.

(WWEA) World Wind Energy Association. 2010. World wind energy report: 2009. March. URL http://www.wwindea.org/home/images/stories/worldwindenergyreport2009_s.pdf [accessed 21 July 2010].

(WTGAC) Wind Turbine Guidelines Advisory Committee. 2010. Wind Turbine Guidelines Advisory Committee Recommendations. March 4. URL http://www.fws.gov/habitatconservation/windpower/wind_turbine_advisory_committee.html. [accessed 6 May 2010]. 
Zafonte, M. \& Hampton, S. 2005. Lost bird-years: quantifying bird injuries in natural resource damage assessments for oil spills. Proceedings, 2005 International Oil Spill Conference. URL http://www.iosc.org/papers/IOSC\%202005\%20a287.pdf [accessed 9 august 2010].

Zafonte, M. \& Hampton, S. 2007. Exploring welfare implications of resource equivalency analysis in natural resource damage assessments. Ecological Economics 61 No. 1: 134-145. 